\title{
LA FÁBULA DE ACTEÓN DE ANTONIO MIRA DE AMESCUA Y LA TRADICIÓN EJEMPLARIZANTE DEL MITO ${ }^{1}$
}

\author{
INMACULADA OSUNA \\ Universidad Complutense de Madrid²
}

Entre la dispersa producción poética de Antonio Mira de Amescua, su Fábula de Acteón aparece como uno de los textos más destacados ${ }^{3}$. Por desgracia, se desconoce

1 Recibido: 30-XI-2009 Aceptado: 24-III-2010

2 Este trabajo se enmarca en las líneas de investigación sobre poesía del Siglo de Oro desarrolladas al amparo del Programa Ramón y Cajal, cofinanciado por el Ministerio de Educación y Ciencia.

3 El texto ha sido publicado en varias ocasiones, según testimonios manuscritos diversos: A. M. Mignone («Per un'edizione critica del poema Acteón y Diana di Mira de Amescua», Studi Ispanici, Giardini, Pisa, 1983, págs. 197-212) utiliza como base el Ms. 7 de la Biblioteca Aprosiana de Ventimiglia; M. de la Campa («La Fábula de Acteón y Diana de Antonio Mira de Amescua», Manuscrt. Cao, I, 1988, págs. 4961), M. T. Beltrán y F. Moya («"La Fábula de Acteón y Diana” de Antonio Mira de Amescua», Anales de Filología Hispánica, 5, 1990, págs. 5-35) y J. E. Taracido (The Poetry of Antonio Mira de Amescua, Tesis University of Missouri-Columbia, 1974, págs. 568-586) siguen el texto del ms. 3888 BNM; estos trabajos recogen las variantes aportadas en los mss. 2244 y 4271BNM (este último sólo en Beltrán y Moya y en Mignone) y en las ediciones de J. N. Böhl de Faber, Tercera Parte de la Floresta de Rimas Antiguas Castellanas, Perthes y Besser, Hamburgo, 1825, págs. 245-257 y A. de Castro, Poetas líricos de los siglos XVI y XVII, Atlas (BAE, LII), Madrid, 1951, págs. 425-428 (en Beltrán y Moya, Campa y Taracido). Para las citas 
el contexto personal y poético en el que el poema se fraguó, si bien parece bastante verosímil que se compusiera durante la estancia napolitana del autor, entre la corte del Conde de Lemos, no mucho antes de $1614^{4}$.

A lo largo de cincuenta y ocho octavas, Mira de Amescua recrea un conocido mito divulgado por las Metamorfosis de Ovidio, aunque también presente en otros testimonios de la Antigüedad, con significativas variantes ${ }^{5}$. En la versión ovidiana, el episodio se engarza a continuación de la historia de Cadmo, abuelo de Acteón, con una anticipación del final funesto del joven y sus «cuernos postizos añadidos» («alienaque cornua fronti / addita», III, 139-140) antes de proceder al relato ${ }^{6}$. La historia se abre con la imagen de «una montaña teñida en sangre de muchas fieras» («Mons erat infectus uariarum caede ferarum», III, 144), como indicio de una jornada intensa de caza. No mucho más detalladas son las palabras de Acteón cuando, ante el calor del mediodía, exhorta al descanso hasta la Aurora siguiente: «Las redes y hierro, compañeros, están empapadas en sangre de fieras, y el día ha sido bastante afortunado» («Lina madent, comites, ferrumque cruore ferarum, / fortunamque dies habuit satis!», III, 148-149). Cerca de allí, en un bosque consagrado a Diana, la diosa, acompañada de sus ninfas, decide aliviarse del calor, según su costumbre, en un manantial oculto en una apartada gruta. Vagando por el bosque, Acteón llega hasta allí y ve la escena. Nada dice Ovidio de su reacción: el interés se centra en los dramáticos gestos de turbación de las ninfas,

me valgo fundamentalmente del texto editado por Mignone, modernizando grafías, puntuación y uso de mayúsculas (igual hago con las de otros textos de la época), y realizando algunas enmiendas, que señalo en nota, a partir de las variantes de los manuscritos citados; en las referencias utilizo números romanos para indicar la octava a que se remite y arábigos para el verso dentro de ésta. La fábula también ha sido objeto de atención en algunos estudios: J. Toledano Molina, «El tema de Acteón en Barahona de Soto y Mira de Amescua», en A. de la Granja y J. A. Martínez Berbel (eds.), Mira de Amescua en candelero. Actas del Congreso Internacional sobre Mira de Amescua y el teatro español del siglo XVII, Universidad, Granada, Granada, 1996, I, págs. 545-552; M. C. García Sánchez, «A propósito de la Fábula de Acteón y Diana, de Mira de Amescua», Mágina, 9, 2001, págs. 81-107.

4 Por una carta de Góngora a Juan de Villegas se sabe que la fábula es anterior a septiembre de 1614, ya que menciona haber pedido una copia a Baltasar Elisio de Medinilla (L. de Góngora, Epistolario completo, ed. de A. Carreira, Pórtico, Zaragoza, 1999, pág. 7); su interés y el ofrecimiento de mostrársela a su corresponsal cuando la reciba hacen pensar que el poema fuera relativamente reciente y no de varios años atrás, cuando su autor aún vivía en España. Mira de Amescua debió de partir para Italia hacia finales de 1610, y allí permanecería hasta noviembre de 1616 (R. Castilla, El arcediano Antonio Mira de Amescua: biografía documental, UNED, Jaén, 1998, págs. 35-37). Para el alcance cultural de la corte napolitana del Conde de Lemos puede verse ahora la tesis doctoral de I. Enciso Alonso-Muñumer, Linaje, poder y cultura: el virreinato de Nápoles a comienzos del XVII. Pedro Fernández de Castro, VII Conde de Lemos, Universidad Complutense de Madrid, 2002 (ahora puede consultarse bajo el título: Nobleza, poder y mecenazgo en tiempos de Felipe III. Nápoles y el conde de Lemos, Madrid, Editorial Actas, 2007).

5 Para la tradición del mito en la Antigüedad pueden verse, entre otros, J. Fontenrose, Orion. The Myth of the Hunter and the Huntress, University of California, Berkeley / Los Ángeles, 1981, especialmente págs. 33-47; C. C. Schlam, «Diana and Actaeon: Metamorphoses of a Myth», Classical Antiquity, 3, 1984, págs. 82-110; y J. Heath, Actaeon, the Unmannerly Intruder. The Myth and its Meaning in Classical Literature, Peter Lang, Nueva York, 1992.

6 Cito por la edición bilingüe de A. Ruiz de Elvira, CSIC, Madrid, 1990. 
que en vano intentan proteger a la diosa de la vista del «intruso», y en la reacción airada de Diana, quien, sin sus flechas a mano, arroja a Acteón el agua que obra la transformación en ciervo. Él no se percata de su metamorfosis, y sin justificar tampoco su reacción, el poeta narra cómo huye con la ligereza propia de su nueva naturaleza, para él sorprendente. Poco después descubre en el agua su actual figura, y en vez de palabras de lamento, sólo logra dar un gemido. En medio de su perplejidad, su jauría descubre la presa y se presta a darle alcance. Acteón, que conserva su entendimiento humano, querría decirles que él mismo es el ciervo al que persiguen, pero no puede articular palabra, como tampoco puede contestar cuando sus eufóricos compañeros lo llaman para que no se pierda el espectáculo de la caza ${ }^{7}$. Finalmente muere despedazado por sus propios perros.

Mira de Amescua recrea el relato ovidiano en una fábula que formalmente mantiene su tono trágico y desgarrado y que en apariencia se deleita en una actualización del episodio por sus valores estéticos intrínsecos, de manera ideológicamente neutra, sin los aditamentos moralizantes que, desde su propia conformación hasta la exégesis posterior, habían formado parte de la tradición del mito, y también sin los matices aleccionadores de otras versiones o alusiones poéticas a las desgracias de Acteón.

Ya esta versión ovidiana insistía en el conflictivo enjuiciamiento del episodio en unos términos morales directamente derivados de la relación de los hechos. Así, se ponía en cuestión la culpabilidad o inocencia de Acteón en su acceso a la fuente y, por consiguiente, si la reacción de Diana debía considerarse como acto de justicia o de crueldad. La actitud de Ovidio, a veces interpretada en clave autobiográfica ${ }^{8}$, parece decantarse por la inocencia de Acteón en su acto de haber visto lo que no debía ver. En su anticipación inicial del trágico destino, Ovidio contrapesa el concepto de crimen, por una parte, y por otra el de falta de la Fortuna o error, decantándose por esto último («at bene si quaeras, Fortunae crimen in illo, / non scelus inuenies; quod enim scelus error habebat?», III, 141-142) ${ }^{9}$, y con ello desdibujando el sentido de premeditación

7 Sobre tal incapacidad para el lenguaje articulado véase J. Heath, op. cit., págs. 65-75.

8 Cf., por ejemplo, A. Luisi y N. F. Berrino, Culpa silenda. Le elegie dell'error virgiliano, Edipuglia, Bari, 2002, págs. 7-35. Una muestra de cómo la conexión biográfica se transmitió junto con la tradición alegórica del mito puede verse en Metamorphoseos Vulgare, novamente stampato. diligentemente corretto e historiato, Georgio de Rusconi, Venecia, 1517, con la traducción de Giovanni de Bonsignore: «Allegoria. Ovidio pose questa fabula che la dea fesse ingiustamente contra de Ateon per exempio: percio che egli fu mandato in exilio da Octaviano perche gli vide lo imperatore vituperosamente carnalmente peccare. Overo egli disse perche egli vide limperatrice nuda si come nel exordio dinanci se dechiara. Questa fabula si expone in altra forma piu morale: cioe Ateon fu uno anticho cacciatore e fu maestro de le cacie [...]» (fol. 18v); a continuación, sigue la explicación de Fulgencio.

9 Sobre las implicaciones de crimen, scelus, error, en relación con las vicisitudes biográficas de Ovidio y sus composiciones del exilio, véase A. Luisi y N. F. Berrino, op. cit., págs. 17-18 y 20-21. 
o conocimiento de causa en la transgresión cometida ${ }^{10}$. Curiosamente, en el punto crucial de la aproximación a la fuente, aparece el verbo errar («per nemus ignotum non certis passibus errans», III, 175), con un valor espacial sobre el que quizás esté también resonando el sentido moral del término; pero de modo aún más explícito, para Ovidio, «los hados lo llevaban» («illum fata ferebant», III, 176), fuerza externa, al fin, a la responsabilidad humana. Como cierre argumental del episodio, aparece una Diana vengativa, que no sólo ha privado a Acteón de su forma humana, sino que además se complace en su lamentable final: «dicen que no se sació la cólera de Diana [...] hasta que acabó aquella vida víctima de heridas innumerables» («nec nisi finita per plurima uulnera uita / ira pharetratae fertur satiata Dianae», III, 251-252). A esto se añade la explícita coda final: «a unos les pareció que la diosa había sido más rigurosa de lo justo, otros la aprueban y la llaman digna de su austera virginidad» («aliis uiolentior aequo / uisa dea est, alii laudant dignamque seuera / uirginitate uocant», III, 253-255).

Tal vez Ovidio contrapesara esta posibilidad exculpatoria con una tradición mitológica en la que la falta de Acteón no quedaba tan desdibujada. Varias versiones habían incluido -o incluirían después- una actitud transgresora activa por parte de éste, a veces con variación en los protagonistas y en la entidad real de la metamorfosis. En la más arcaica, Artemisa simplemente hacía enloquecer a los perros contra su amo, pero actuaba a instancias de Zeus, deseoso de castigar las pretensiones sexuales del joven hacia Sémele, amante del dios y tía de Acteón. Otras variantes del mito sí situaban a Diana como objeto de una ofensa patente por parte del joven, bien de naturaleza sexual (con un intento de violación a la diosa), bien por un acto de soberbia (con la jactancia de éste a propósito de sus cualidades cinegéticas). La escena del baño de Diana no era, además, constante en esa maraña de testimonios, literarios o iconográficos, aunque ya aparece, con anterioridad a Ovidio, en Calímaco ${ }^{11}$. Por otra parte, si en estos dos autores se señalaba la «inocencia» de Acteón en aquel encuentro fortuito, tampoco faltan versiones posteriores que evidencian en él una «mirada curiosa» («curioso optutu»), como la califica Apuleyo (Metamorfosis, II, 4), e incluso Nonno de Panópolis (Dionisíacas, V, 287-532) lo presenta subido a un árbol espiando a la diosa, ya con total premeditación ${ }^{12}$. En definitiva, en la tradición tanto anterior como posterior a las Metamorfosis ovidianas, la muerte de Acteón atacado por sus propios perros se

10 Véase J. Heath, op. cit., pág. 61; L. Schwatz, op. cit., págs. 552-553.

11 Se trata de una breve alusión del Himno V (Al baño de Palas), donde se contrasta la relativamente benigna suerte de Tiresias, ciego tras haber visto desnuda a Palas, aunque en contrapartida dotado del don de profecía, con la de Acteón: «y ni esas correrías compartidas [entre Acteón y Ártemis], ni las flechas que juntos arrojarán en las montañas, podrán salvarlo cuando, involuntariamente, vea el placentero baño de la diosa» (Himnos, epigramas y fragmentos, trad. de L. A. de Cuenca y Prado y M. Brioso Sánchez, Gredos, Madrid, 1980, pág. 80).

12 Utilizo la traducción de S. D. Manterola y L. M. Pinkler, Gredos, Madrid, I, 1995, especialmente págs. 183, 188 y 190-191. 
hallaba con frecuencia justificada narrativamente por algún grado de culpabilidad en el joven.

Junto a esta justificación interna al relato, otra línea exegética, ya más alejada del sentido literal de la fábula, se expandió hacia sentidos presuntamente escondidos que las interpretaciones evemeristas y morales se encargaron de desentrañar ${ }^{13}$. Dejando aparte las alegorías de inmediato sentido cristiano, que forzaron el mito hasta identificar con Cristo a la figura de Acteón ${ }^{14}$, con un simbolismo que ahora no viene al caso, destaca la interpretación ejemplarizante de éste en torno al motivo de la caza.

Incluso dentro de este preciso motivo, las explicaciones también seguían varias direcciones. Por ejemplo, Fulgencio (Mitologías, III, 3), citando a Anaxímenes, despojaba de entidad corporal a la figura femenina para considerarla de manera alegórica, en virtud de la identificación mitológica de Diana con la caza. Así, el hecho de haber visto Acteón desnuda a Diana significaba el reconocimiento de éste, ya en edad madura, de los peligros de la caza, con el consiguiente abandono de ésta, que quedaba expresado alegóricamente en el carácter medroso del ciervo en que se había convertido; sin embargo, no renunció a sus perros, que ya sin ningún provecho, consumieron sus bienes, motivo por el cual se dijo que éstos habían devorado a su amo. Boccaccio, en su Genealogía de los dioses paganos, cita a Fulgencio y su fuente ${ }^{15}$, la General Estoria de Alfonso $X$ también se hace eco de la misma interpretación, sin precisar a qué «comentaristas» de Ovidio sigue ${ }^{16}, \mathrm{y}$, con paralelismos de contenido evidentes con respecto a este último, aún recuerda tan elaborada alegoría Juan Pérez de Moya en su Filosofía secreta, de $1585^{17}$.

Otras declaraciones, sin tanto detalle, sólo señalaban en el desastroso final de un Acteón no arrepentido de sus aficiones cinegéticas las consecuencias de un

13 Un panorama general de estas derivaciones de los mitos puede verse en J. Seznec, Los Dioses de la Antigüedad en la Edad Media y el Renacimiento, Taurus, Madrid, 1983, especialmente págs. 19-124; por lo que respecta a España véase Suzanne Guillou-Varga, Mythes, mitographies et poésie lyrique au Siècle d'Or espagnol, Didier, París, 1986, I, págs. 38-96.

14 Así en el Ovide Moralisé, III, vv. 604-669 (ed. de C. de Boer, Martin Sändig, Wiesbaden, I, 1966, pág. 312-313). Sobre diversas cristianizaciones del mito en Francia a finales del siglo XV, véase C. Carena, «I grandi di Francia alle prese con le Metamorfosi», en G. Papponetti (ed.), Metamorfosi. Atti del Convegno Internazionale di Studi Sulmona, 20-22 Novembre, 1994, Regione Abruzzo y Centro Ovidiano di Studi e Ricerche, Sulmona, 1997, págs. 309-326, concretamente pág. 311.

15 Libro V, Capítulo XIV. Utilizo la traducción de M. C. Álvarez y R. M. Iglesias, Editora Nacional, Madrid, 1983, pág. 326.

16 Las Metamorfosis y las Heroidas de Ovidio en La General Estoria de Alfonso el Sabio, ed. de B. Brancaforte, Hispanic Seminary of Medieval Studies, Madison, 1990, págs. 50-57; para la interpretación alegórica, págs. 54-55.

17 Incluye el mito en el Libro V (que precisamente «Contiene fábulas para exhortar a los hombres huir de los vicios y seguir la virtud»), Capítulo V (ed. de C. Clavería, Cátedra, Madrid, 1995, págs. 579-580). 
inmoderado afán por la caza. Los matices a propósito de la pareja dejación de las ocupaciones consideradas propias variaban, posiblemente en paralelo a mentalidades de época o autor. En el siglo IV a. C., Paléfato señala que en tiempos de Acteón todos los hombres trabajaban con sus manos, sin valerse de siervos y cultivando cada uno sus propios campos, y que por tal motivo la despreocupación de éste hacia los asuntos domésticos en favor de la caza causó su ruina ${ }^{18}$. Alfonso X, que alterna esta versión con la alegoría antes indicada, muestra ya una aplicación moral de contexto cortesano; así, para él, Acteón es un infante tan aficionado a la caza, que por la cantidad de perros que llevaba y de hombres que se acogían a su generosidad, «se desfizo por y su fazienda e paro muy mal por y aquel derecho que ouiera en el reyno» ${ }^{19}$. Juan de Mena, en su comentario a la Coronación al Marqués de Santillana, ya no dirige el aleccionamiento de la fábula concretamente hacia quien tiene derechos sobre el reino, aunque mantiene su condición caballeresca y sus obligaciones de administración patrimonial ${ }^{20}$. Pérez de Moya, siguiendo de cerca a Mena en léxico y sintaxis, elimina evocaciones típicamente caballerescas, hablando simplemente de «cualquier hombre de grande estado, que en lugar de darse a aprender buenas costumbres para hacerse apto de administrar bien su república se da a la caza» ${ }^{21}$. Pedro Sánchez de Viana, en las anotaciones a su traducción de las Metamorfosis, parafraseando también a Mena, habla de «cualquiera hombre de gran estado y autoridad» $\mathrm{y}$, con nuevas connotaciones tanto religiosas como intelectuales, detalla como obligaciones pospuestas por la caza el «estudio de las letras y buenas costumbres, para satisfacer al ministerio en que Dios le puso ${ }^{22}$. Con todo, y teniendo en cuenta la aceptación de la caza como ejercicio nobiliario de sentido cuasimilitar, tampoco extraña que Diego López, en su comentario de uno de los Emblemas

18 Hay traducción española en Mitógrafos griegos, ed. de M. Sanz Morales, Akal, Madrid, 2002, págs. 226-227. Para la divulgación de mitografías breves como ésta hay que tener en cuenta las ediciones conjuntas; valga de ejemplo un volumen donde, junto con textos astrológicos -también de conexiones mitológicas a través de los catasterismos-, se recoge, con un preciso reclamo a la lectura de «los poetas», a Higinio, Paléfato, Fulgencio, etc.: C. Iulii Hygini Augusti liberti Fabularum liber, ad omnium poetarum lectionem mire necessarius, et nunc denuo excusus. Eiusdem Poeticon Astronomicon Libri quatuor. Quibus accesserunt similis argumenti, Palaephati de fabulosis narrationibus, liber I, F. Fulgentii Placiadis episcopi Carthaginensis Mythologiarum Libri III, Eiusdem de uocum antiquarum interpretatione, Liber I, Phurnuti De natura deorum, siue poeticarum fabularum allegorijs, speculatio, Albrici philosophi de Deorum imaginibus Liber, Arati [Phaenomenon] fragmentum, Germanico Caesare interprete, Eiusdem Phaenomena graece, cum interpretatione latina, Procli De Sphaera, Graece et Latine, Ioannes Hervagius, Basilea, 1549.

19 Op. cit., pág. 54.

20 «Por Anteón podemos entender qualquier hombre de gran estado e manera así como era este infante, el qual, en lugar de darse a aprender buenas costumbres porque fuese apte e merecedor de administrar bien tan alto estado como el de la cauallería, dase a la caça e destribuye todo quanto tiene en perros e canes non procurando la honor e acrecentamiento de la república nin pugnando por la defender», M. A. Corral Checa, La Coronación de Juan de Mena, Universidad de Córdoba, Córdoba, pág. 180.

21 J. Pérez de Moya, op. cit., págs. 578-579.

22 P. Sánchez de Viana, Las transformaciones de Ovidio: Traducidas del verso Latino en tercetos y octavas rimas... Con el comento, y explicación de las Fábulas reduciéndolas a Filosofía natural y moral, y Astrología e Historia, Diego Fernández de Córdoba, Valladolid, 1589, fol. 70r. 
de Alciato, intentara atenuar el mensaje disculpando a los nobles aficionados a la caza, pero criticando a los estudiantes y «oficiales» que desatienden sus obligaciones por ella $a^{23}$

El maleable muestrario de consideraciones morales en torno a la fábula no acaba aquí. Baste recordar brevemente otras dos menos significativas para el poema que ahora me ocupa, aunque igualmente ilustrativas de las múltiples direcciones que podía tomar la interpretación mitológica: el consejo hacia quienes, como Acteón con sus perros, dispenden su hacienda con hombres de mala vida (tema en el que, entre otros autores, incide Alciato, y a la zaga, sus comentaristas ${ }^{24}$ ), y la advertencia hacia quienes se muestran curiosos en exceso por cosas que no les conciernen ${ }^{25}$.

Las recreaciones poéticas españolas del episodio no se sustrajeron del todo a esta tradición moralizante. Así, la Fábula de Acteón en coplas reales de Cristóbal de Castillejo presenta una «alegoría y moralidad» separada del desarrollo narrativo donde, sólo con ligeras variantes interpretativas, se exponen algunas de las ideas ya apuntadas ${ }^{26}$. Sin tal delimitación textual, la Fábula de Acteón de Barahona de Soto también da pie, según documenta José Lara Garrido a partir de unos comentarios en los Diálogos de la Montería del mismo autor, a una explicación moral de la metamorfosis, según la cual la inclinación y rendimiento de Acteón al vicio se manifiesta en una pareja transformación del cuerpo ${ }^{27}$. Por su parte, Lía Schwartz ha puesto de relieve varios sonetos en torno a la figura de Acteón que retoman tanto el motivo de la mirada «prohibida», o que causa sufrimiento al amante, como el de la reconvención por la excesiva afición a la caza ${ }^{28}$.

23 D. López, Declaración magistral sobre los emblemas de Andrés Alciato con todas las Historias, Antigüedades, Moralidad y Doctrina tocante a las buenas costumbres, Juan de Mongastón, Nájera, 1615, fol. 164v-165r.

24 Emblemas, LII, In receptatores sicariorum ('sobre los que se rodean de rufianes'). Véase ed. de S. Sebastián, Akal, Madrid, 1985, págs. 86-88, también con referencia al comentario de Diego López. El del Brocense se muestra más parco en cuanto a esa precisa interpretación (F. Sánchez de las Brozas, Comment. in And. Alciati Emblemata, Gulielmus Rovillius, Lyon, 1573, págs. 194-196).

25 Ya Fulgencio iniciaba su presentación del mito de Acteón con sentencia al respecto: «Curiositas semper periculorum germana detrimenta suis amatoribus nouit parturire quam gaudia» (Opera, ed. de R. Helm y J. Préaux, Teubner, Stuttgart, 1970, págs. 62-63). El motivo alcanzó, entre los autores del siglo XVI, a Pérez de Moya («Amonéstanos también esta fábula que evitemos saber secretos ajenos», op. cit., pág. 580) o a Sánchez Viana («También con esta misma ficción nos amonestan a que no seamos curiosos con demasía cerca de las cosas que no nos tocan, porque a muchos ha costado caro saber los secretos de los príncipes y reyes» (op. cit., fol. 70r).

26 C. de Castillejo, Fábulas mitológicas, ed. de B. Periñán, Mauro Baroni, Viareggio, 1998, págs. 85-89 (Texto) y 121-130 (Notas). Véase también M. D. Beccaría Lago, Vida y obra de Cristóbal de Castillejo, RAE, Madrid, 1997, págs. 379-382.

27 J. Lara Garrido, La poesía de Luis Barahona de Soto (lírica y épica del manierismo), Diputación Provincial, Málaga, 1994, págs. 160-162.

28 L. Schwartz, «De la erudición noticiosa: el motivo de Acteón en la poesía áurea», en A. Vilanova (ed.), Actas del X Congreso de la Asociación Internacional de Hispanistas, PPU, Barcelona, 1992, I, págs. 551-561. Con respecto al tratamiento del mito en contextos amorosos, pueden verse también ejemplos en la poesía francesa: G. Mathieu-Castellani, Mythes de l'Éros baroque, Presses Universitaires de France, París, 
El planteamiento de la Fábula de Acteón de Mira de Amescua quizás no sea tan ajeno a esta tradición exegética como en principio aparenta, aunque, desde luego, hay que reconocer que las potenciales sugerencias aleccionadoras no apuntan inequívocamente hacia un único sentido. Por una parte parecen acentuarse los rasgos de una posible «culpabilidad» de Acteón en torno a la actividad cinegética y de manera más vaga, y hasta cierto punto disculpada, algún indicio de predisposición sensual por su parte; pero también es verdad que algunas consideraciones subrayan, incluso más allá de las indicaciones de Ovidio, la severidad de la diosa.

Aunque posteriores en el desarrollo narrativo, voy a centrarme primero en estos aspectos relacionados con la escena del baño, la posible culpabilidad de Acteón y el rigor de Diana, con observaciones más dispersas en el poema, para dejar para el final las aportaciones de Mira de Amescua a propósito del motivo de la caza, con un desarrollo relativamente más compacto, y aún más apartado del original ovidiano.

Para ello hemos de partir de la octava XXIII, donde Acteón inicia su vagar por el bosque. Ovidio anteponía la escena del baño, y simplemente atribuía a los hados el hecho de que el joven se encaminara a la fuente. Mira de Amescua opta por romper con la secuencia temporal, que exigía que los preparativos del baño de Diana fueran anteriores a la llegada de Acteón; así, prolongando un poco más su atención a las acciones del joven, no disgrega el tránsito -y eficaz contraposición- entre el ansiado descanso de la comitiva tras la intensa jornada de caza y el errabundo paseo de Acteón. Significativamente, el autor había omitido la exhortación de Acteón a sus acompañantes para dejar la caza hasta el día siguiente, evitando con ello presentar al protagonista con una iniciativa contraria a la imagen de «perpetuo cazador» $(\mathrm{V}, 2)$ que Mira de Amescua quiere resaltar. La curiosidad que algunas versiones del mito atribuían a la mirada de Acteón en la escena del baño caracteriza igualmente aquí al personaje, pero transpuesta inicialmente a un plano distinto: frente a la fatiga de sus compañeros, «sólo está en el Príncipe curioso / el natural sosiego con violencia» (XXIII, 3-4). Cierto toque de reprensión parece esconderse en esa contraposición entre los límites naturales de la condición humana que llaman al reposo y la «violencia» que éste ejerce en el ánimo del príncipe, pero poco más llega a concretar el poema. Es difícil saber hasta qué punto pudo dejar el autor sobrentendido en el paseo de Acteón un nuevo intento de avistar caza, como parecen interpretar Antonio Pérez Sigler y, más explícitamente, Felipe $\mathrm{Mey}^{29}$. Lo cierto es que Mira de Amescua combina la intervención del hado, a la

\section{1, págs. 51-100.}

29 Los matices radicaban en la interpretación de «dilatata parte laborum»: «[...] el bello nieto / de Cadmo, alguna parte dilatando / de su trabajo, por el monte incógnito / errando [...]» (Los quince libros de los Metamorfoseos... Traducidos en verso suelto y octava rima por Antonio Pérez, con sus alegorías al fin de cada libro, Juan Perier, Salamanca, 1580, fol. 58r); «el trabajo y la caza dilatando, / Acteón en la selva se 
que de manera exclusiva apelaba Ovidio, con justificaciones más racionales apoyadas en esa «curiosidad» o carácter inquieto del protagonista, ya que los pasos del cazador aparecen guiados por su interés por conocer el origen del arroyo ${ }^{30}, \mathrm{y}$ más tarde por una voz no identificada hasta varias estrofas después.

Tal voz pertenece a una de las ninfas que, sin participar del baño de sus compañeras, entona un breve himno a Diana. La escena no aparece en Ovidio, ni en traducciones suyas italianas y españolas ${ }^{31}$, ni tampoco en las obras u opúsculos citados con interpretaciones alegóricas del mito; en principio parece, pues, de propia invención del autor, acudiendo a un tópico narrativo común. La voz femenina permite al poeta reorientar de manera implícita la «curiosidad» del joven Acteón hacia un plano potencialmente sensual, hasta ahora ausente en su caracterización, al tiempo que su paso cauteloso, en alguna medida evocador de sus estrategias de caza, parece sugerir, no la precipitación inocente, sino cierta conciencia de un inminente encuentro:

objeto quiso dar, como al oído,

a los ojos; también suspende el paso,

que la razón del hombre no consiente

que tenga más prudencia una serpiente.

Lógicamente, detalconciencia no sepuedeinferir aún una actitud intrínsecamente transgresora, pero la estrofa XXXVIII, lejos de la parquedad expresiva del texto ovidiano, explora la reacción de Acteón prodigándose en la imagen del voyeur que desarrollan otras versiones del mito. En esa reacción entran en lid sentimientos enfrentados: los ojos «ufanos, / del objeto gentil se glorïaban», y «atrás quiso volver, y los humanos / afectos esta acción le perturbaban, / que puesto en confusión y en alegría, / el deleite excedió a la cortesía». La exhortación directa del sujeto poético hacia el protagonista, también sin apoyo en el texto ovidiano, aunque quizás inspirada en intervenciones

emboscaba» (Del Metamorfoseos de Ovidio en Otava rima traducido por Felipe Mey, Felipe Mey, Tarragona, 1586, pág. 148).

30 Ya en Alfonso $X$ aparecía esa curiosidad por el origen del arroyo, a la que luego se añade cierto grado de voluntad en la contemplación de las ninfas: «Pues que llego Acteon al arroyo que descendie daquella fuent, pagos mucho de las sombras de los aruoles [...] e fue yndo por ell arroyo arriba por llegar a la fuent dont nascie e ueer la con sabor que auie ende; e subio tanto que uino a aquel campo o la fuent nascie, e uio las duennas como se bannauan. E maguer que ueye quel uerien ellas, nin se quiso encrobir que nol uiessen, nin dexo de yr e lear fast dont le uerien» (op. cit., pág. 52).

31 Aparte de las ya citadas en las notas $n^{\circ} 20$ y 27, he tenido en cuenta también: Le trasformationi di M. Lodovico Dolce. In questa quinta Impressione da lui in molti luoghi ricorrette, Gabriel Giolito de Ferrari, Venecia, 1558, págs. 64-67; Le Metamorphosi d'Ovidio in ottava rima col testo latino appresso, nuovamente tradotte da M. Fabio Maretti Gentilhuomo senes, Bologninum Zalterium et Guerreos fratres, Venecia, 1570, págs. 83-89; y Le Metamorfosi di Ovidio ridotte da Giovanni Andrea dell'Anguillara in ottava rima, Francesco de' Franceschi, Venecia, 1563, fol. 35r-37v. También la traducción española de Jorge de Bustamante, Las metamorfoses, o Transformaciones del muy excelente poeta Ovidio, repartidas en quince libros y traducidas en castellano, Juan Stelsio, Amberes, 1551, fol. 43r-45r. 
similares en otros pasajes de las Metamorfosis ${ }^{32}$, da por supuesto el deseo en Acteón, calificado de «vanos antojos» o «loco ardor» (XL, 3-4). Mira de Amescua, de nuevo atento a las reacciones del joven, lo presenta, tras recibir el agua salpicada por la diosa, con una escasa conciencia de la situación («y al triste, que el calor le ha fatigado, / favor, y no castigo, parecía», XLII, 5-6), quizás incluso con unas falsas esperanzas, que, aun por camino distinto, recuerdan al Acteón de Barahona de Soto, el cual, sin percatarse de los cuernos que coronan su frente, interpreta como prometedora simpatía las risas de las ninfas por su nueva forma ${ }^{33}$.

Pese a todo ello, Mira de Amescua no deja de apelar al hado o destino, más que a un error personal propiamente dicho, siguiendo la postura ovidiana. Además, si en alguno de los versos citados ya aparece cierta justificación o comprensión de los «humanos afectos» que llevan al joven a desear a la diosa, tampoco evita desarrollar en torno a ésta una imagen de atracción y arbitrariedad que, en cierto modo, atenúa la culpabilidad del deseo. Dejando de lado los procedimientos que acentúan el elogio de la belleza de la diosa, mencionaré al respecto sólo dos referencias mitológicas, ausentes del texto ovidiano, que, en distinta medida, pueden ser significativas. En el pasaje en que Diana es asistida por sus ninfas hasta quedar desnuda, Ovidio indicaba que la diosa entregó a una de ellas sus armas: una jabalina, la aljaba y el arco («nympharum tradidit uni / armigerae iaculum pharetramque arcusque retentos», III, 165-166); Mira de Amescua manipula la imagen con intención casi emblemática para asociarla al propio Cupido, haciendo desaparecer por completo la jabalina: «Despójanla del arco y las saetas, / con que parece Amor, y de amor mata» (XXXI, 1-2) ${ }^{34}$. Si esta previa identificación Diana-Amor ya prepara la previsible reacción del joven, su deseo también queda justificado después, de manera completamente explícita, por la propia dinámica de relaciones entre diosas y mortales en el mundo mitológico. Así, en la

32 Así, por ejemplo, sin salir del mismo libro, con la fábula de Narciso: «Credule, quid frustra simulacra fugacia captas? / Quod petis, est nusquam; quod amas, auertere, perdes! / Ista repercussae, quam cernis, imaginis umbra est: / nil habet ista sui: tecum uenitque manetque, / tecum discedet, si tu discedere possis» (III, 432-436).

33 «Como de hombre de mentira, / no han vergüenza, mas les place; / porque la vergüenza nace / del seso del que nos mira. / Y él, viéndolas tan mudadas, / como aún la suya ignorase, / ¡oh necedades usadas! / ¿quién duda que no pensase / que le eran aficionadas? / Porque el cuitado no siente / de qué se alegra la gente: / que siempre el cornudo fue / el postrero que los ve, / porque los tiene en la frente», en F. Rodríguez Marín, Luis Barahona de Soto. Estudio biográfico, bibliográfico y crítico, Sucesores de Rivadeneyra, Madrid, 1903, págs. 658-659. Hay ahora también edición en L. Barahona de Soto, Fábulas mitológicas, ed. de A. Cruz Casado, Ayuntamiento de Lucena, Lucena, 1999.

34 Quizás esté subyaciendo el motivo del «robo de las armas de amor» (M. P. Manero Sorolla, Imágenes petrarquistas en la lírica española del Renacimiento. Repertorio, PPU, Barcelona, 1990, pág. 111; J. G. Fucilla, Estudios sobre el petrarquismo, CSIC, Madrid, 1960, págs. 163-164): Cupido se despoja de las armas y ese momento es aprovechado por la dama para hacerse con ellas y herir a continuación el amante; aquí se mantiene la acción de desarmarse y la identificación de la figura femenina con Cupido por las armas que lleva, pero en este caso son propias, no hurtadas. 
estrofa XL, se especula sobre lo diferente que podría haber sido la suerte de Acteón si no fuera Diana la sorprendida desnuda, y lo hace con un rasgo de humor un tanto inesperado en un poema que calificaríamos como "serio», aunque también se puede recordar un precedente en la Fábula de Acteón de Barahona de Soto, a propósito de similar juego lingüístico ${ }^{35}$. Dice el poema de Mira de Amescua:

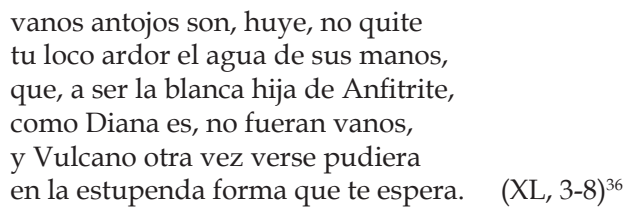

En la estrofa siguiente, la hipótesis no juega ya con un cambio de diosa, sino de pretendiente y, como también hiciera Barahona de Soto -éste añadiendo ejemplos de ofensas a Diana más agresivas que la de Acteón ${ }^{37}$-, acude a la figura de Endimión, quien sin duda habría encontrado más benevolencia en Diana. Con ambas hipótesis, queda, pues, subrayada la arbitrariedad que, aun con el componente de culpa que muestra el Acteón de Mira de Amescua, entraña la reacción de la diosa.

Por el contrario, tampoco falta algún pasaje que modifica sensiblemente la imagen de una Diana totalmente desconsiderada hacia la tragedia del joven. Así las palabras que acompañan el gesto decisivo de la diosa de arrojar agua a Acteón para provocar la metamorfosis, aun manteniendo el mensaje, carecen de la ironía cruel de la formulación ovidiana, que retaba al joven a referir haberla visto desnuda, si es que podía; además, Mira de Amescua añade una autojustificación de Diana que relaciona los cuernos del futuro ciervo - posiblemente en nueva referencia velada a la connotación jocosa contemporánea del término- con los que ella misma ostenta en su identificación con la Luna:

\footnotetext{
Huya con cuernos, pues que acción villana no ha sido convertirle en tal figura, si yo me muestro en forma semejante, al poniente una vez y otra al levante.
}

Además, con igual identificación, aunque dando apoyo a una cronografía, frente a la Diana ovidiana que no sacia su venganza hasta ver despedazado a Acteón, la de Mira de Amescua acaba mostrando su dolor por el final del joven:

35 Véase nota $\mathrm{n}^{\mathrm{o}} 31$.

36 Es decir, los «antojos» de Acteón no serían «vanos» si la hija del mar, Venus, en vez de Diana, fuera la sorprendida en el baño, de modo que Vulcano, otra vez, como ya antes a causa del también mortal Adonis, pudiera verse como inmediatamente se verá Acteón: con cuernos.

37 En F. Rodríguez Marín, op. cit., págs. 665-668. 


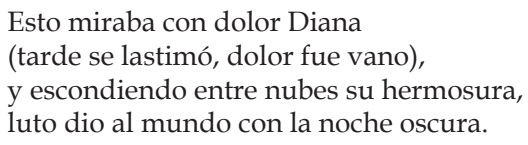

Si la «culpabilidad» de Acteón queda de algún modo atenuada en estos procedimientos que, en sentidos contrapuestos, acentúan los procesos anímicos de los personajes con respecto al componente sensual del relato, el tema de la caza, casi externo al núcleo del conflicto en la versión ovidiana, va a encontrar aquí un destacable desarrollo, de sentido mucho más nítido.

Ya en su comentario de la fábula de Mira de Amescua, Concepción García Sánchez ha señalado entre las estrofas cuarta y décima la insistencia en la desmedida afición a la caza por parte del protagonista, con la caracterización de éste como «perpetuo cazador» y con la precisión de las distintas piezas cobradas y las técnicas utilizadas para ello ${ }^{38}$. En efecto, si en Ovidio el carácter habitual de las batidas de Acteón sólo quedaba sobrentendido y el éxito de la jornada de caza aquel funesto día venía expresado de forma genérica, en Mira de Amescua las referencias se desdoblan y amplifican de modo llamativo.

En primer lugar, entre las estrofas cuarta y octava se insiste en las actividades cinegéticas de Acteón como ejercicio no sólo habitual sino también absorbente, tal como ponen de relieve los versos iniciales de esta sección: «Divertido a otra acción [es decir: apartado para cualquier otra acción] y al monte dado, / correr su juventud dejaba Acteo ${ }^{39}$ (IV, 1-2). En consonancia con las interpretaciones moralistas del mito, aunque de manera más sutil, esa otra acción postergada quizás pudiera deducirse de los primeros versos del poema, que presentan a Cadmo «atento a las políticas acciones / de un nieto, a heroica fama dirigidas» (I, 5-6 $)^{40}$; en esta estrofa cuarta, sin mayores precisiones, la idea de una juventud «dejada correr» parece entrañar por sí misma cierto reproche. Mucho de lo que a continuación viene bien podría considerarse como elogio enfático de sus habilidades, pero no faltan tampoco expresiones e imágenes de ambiguo sentido último. Ambivalente resulta, desde luego, la ponderación inmediata: «¿Qué selva con furor no ha fatigado, / suspendiendo el cansancio en el deseo?» (IV, 3-4); la valoración del sintagma «con furor» depende, obviamente, de la consideración previa del lector hacia la caza: puede evocar el denuedo heroico para quien la estime como noble ejercicio propio de caballeros, o por el contrario la enajenación de quien

38 C. García Sánchez, art. cit., pág. 87.

39 En el manuscrito de la Biblioteca de Ventimiglia, «Anteo». He optado por la forma más próxima a la latina, pero aparecen variantes del nombre propio en las distintas fuentes: Anteo, Ancteo, Acteo (en posición de rima), y las correspondientes Anteón, Ancteón, Acteón.

40 La significación de este último verso con respecto a las obligaciones propias del rango de Acteón ha quedado desdibujada en los demás testimonios conocidos, que leen «dueño hermoso de ambas vidas». 
se entrega inmoderadamente a ella; también la contraposición entre cansancio y deseo puede sugerir la positiva perseverancia más allá de los límites físicos, aunque más adelante en el poema, como se ha apuntado, tal resistencia al «natural descanso» encamina precisamente al protagonista hacia la tragedia.

La caracterización como "perpetuo cazador» prácticamente encabeza las estrofas dedicadas a la descripción de sus prácticas cinegéticas (estrofas V-VIII), cuya potencial consideración negativa tampoco llega a definirse por completo:

Con verde y engañosa red cubría, perpetuo cazador, sendas estrechas, camino que a las aguas conducía, del cándido cristal y del sol hechas; cercaba el monte al asomar del día alcanzando las plumas de sus flechas simple corzuelo, que buscando vino, huyendo humana voz, prisión de lino.

El cauto pie otra vez apenas mueve entre el verde despojo del invierno y al ciervo que el cristal del valle bebe o que pace del monte el vello tierno tira el venablo, y aun veloz se atreve (¡bizarra juventud!) a asir el cuerno, que parece en su frente seca rama, y el ya no libre ciervo en vano brama.

Tal vez, árbol fingido, al margen verde del espejo que dio a Narciso amores, con la codicia el movimiento pierde, el cuerpo transformado en rama y flores; las falsas hojas el sirguero muerde, cortan la nueva flor los ruiseñores $\mathrm{y}$ al gamo que al cristal la sed incita la vida y el licuor de un golpe quita.

O ya, tras de la imagen aparente de un imitado buey o manso toro, que astuto, con el paso negligente, finge a la mies cortar los granos de oro, como suele atender el diligente robador a la presa del tesoro, sigue los saltos de la cabra inquieta, que no esperó de un buey mortal saeta ${ }^{41}$.

Pese a todo, esta aparentemente neutra descripción de técnicas de caza llega a incidir en una idea fundamental en la futura metamorfosis de Acteón, implícita en el relato ovidiano, sugerida en algunas interpretaciones ejemplarizantes del mito

41 Sigo las lecturas de la edición de Mignone, op. cit., salvo en las siguientes correcciones: «Tal vez, árbol fingido, al margen verde», en vez de la lectura del último sintagma «el margen verde»; «y al gamo que al cristal la sed incita», en vez de «y el gamo [...]»; «de un imitado buey o manso toro», en vez de «de un imitado bien, y manso toro». 
y que Mira de Amescua salpica, casi inadvertidamente, a lo largo de su poema: las situaciones de indefinición entre la condición humana y la animal (o aquí en algún momento incluso la vegetal).

De este modo, en la estrofa VII, el cazador aparece renunciando, en su inmoderación (literalmente «su codicia»), al movimiento que caracteriza la vida humana, en una voluntaria metamorfosis: «Tal vez, árbol fingido, [...] / con la codicia el movimiento pierde, / el cuerpo transformado en rama y flores». En la estrofa siguiente, igualmente voluntaria es la apariencia de buey o toro, utilizada para atrapar a una cabra, y que, como en la anterior mención de la «codicia», aquí se asimila a otro comportamiento ilícito: la diligencia del ladrón en acechar el «tesoro» que desea. Incluso más allá de ese abandono momentáneo de apariencias humanas, no parece casual que justo antes se haya utilizado el símil de una «seca rama» para aludir a la cornamenta del ciervo tomado como presa, y que los cuernos también caractericen a los fingidos animales en que se transmuta el cazador, acentuando así el paralelismo con la futura indeseada metamorfosis.

En la estrofa IX una directa exhortación al joven desde el sujeto poético, ausente en el relato de Ovidio al igual que la mencionada a propósito del baño de Diana, no deja ya lugar a dudas de la perspectiva adecuada, con la censura del «espíritu obstinado» del joven («sosiega ajeno / de afán y da a tu vida otro cuidado») y la premonición de su destino («si no sosiegas, / amarás el descanso que les niegas» ${ }^{42}$ ).

La octava siguiente sirve de bisagra al segundo bloque de la amplificación que realiza Mira de Amescua en torno al motivo de la caza, el relativo al día en que se consumará el trágico destino del joven, presentado no como una jornada más -como podría sugerir, por omisión, el texto de Ovidio-, sino como fruto de un empeño aún más ambicioso: «Cazar quiso una vez con más grandeza» $(X, 5)$. Siguiendo la secuencia de referencias que aludían a la codicia, se identifica el «apetito mortal» $(X, 3)$ por la caza con el «avaro amor» $(X, 2)$ que crece con la riqueza (es decir, la avaricia). De nuevo el engrandecimiento de las pretensiones de Acteón se entrevera de expresiones que dejan ver la desmesura: así los versos «aires y montes despoblar quería» $(X, 6)$ o «queriendo no dejar desta manera / ave en el aire, ni en el monte fiera» $(\mathrm{XI}, 7-8)^{43}$.

En las estrofas XIII-XVI se evoca el mundo animal en el que se desenvuelve la escena de caza, casi siempre como presa potencial o efectiva (así, el caso del león, la garza, el ciervo, el jabalí, el conejo), otras veces como imagen agorera de la futura matanza (el buitre), otras como colaborador en ella (el can y el halcón):

42 En el texto editado por Mignone: «amarán».

43 En Mignone: «y en el monte». 
Tiemblen las fieras hoy de los desiertos campos, y tema el rey dellas temido, el que duerme los párpados abiertos, mostrando que aun del sueño no es vencido; del presagio fatal de cuerpos muertos, buitre voraz, se escucha el cruel graznido: oráculo es su olfato, que adivina alguna bruta o racional ruina.

La garza, que eligió senda suprema que el águila emprender apenas osa, y el ala infatigable casi quema, de la región del fuego mariposa, las asechanzas de la tierra tema o espere sus desdichas animosa, porque es, si la venganza da osadía, ${ }^{44}$ al ave y cazador infausto día.

El codicioso can aquél desata, que ya su inclinación le solicita; grillos y antojos de cendal y plata al ciego y preso halcón el otro quita; este que el ciervo temeroso mata sabueso y jabalí a batalla incita, y en los vientos, al caso detenidos, andan envueltas voces y bramidos.

Capitán desta guerra, quiere Acteo $^{45}$ matar con sangre bruta que ha sacado la sed insaciable a su deseo en la fatiga a que nació inclinado. ¡Oh qué presto de actor verná a ser reo! Sacerdote parece, ensangrentado, que a la llama vestal víctima aplica $\mathrm{y}$ varios animales sacrifica.

$\mathrm{Ni}$ al tímido conejo, que enemigo tan fuerte no esperó, perdón reserva; niega el hombre piedad y el monte abrigo, ${ }^{46}$ sin respeto del género, a la cierva; las paces hizo el sol, piadoso amigo, que con derecha luz quemó la hierba, y de sombras desnudo el horizonte, huésped del valle fue el terror del monte. ${ }^{47}$

44 En el manuscrito seguido por Mignone: «si la venganza da alegría».

45 En el manuscrito seguido por Mignone: «Anteo» (véase nota ${ }^{\circ} 37$ ).

46 En el manuscrito seguido por Mignone: «niega el hombre y el monte el fiel abrigo». En este caso, parece más adecuada la distribución que establece la lectura de los mss. 2244, 3888 y 4271 BNM (con omisión de la conjunción en el primero).

47 En la edición de Mignone: «fue, terror del monte». Con variantes en el sustantivo (terror, temor, horror), los tres manuscritos citados de la Biblioteca Nacional coinciden en la anteposición del artículo; con él se evita poner en un mismo plano temporal las dos caracterizaciones de Acteón: quien antes había sido «el terror del monte» -tal como se ha ido detallando en los versos anteriores-, ahora se convierte en «huésped del valle». 
Más allá de la anticipación de la inversión de papel que le aguarda a Acteón, claramente enunciada en la estrofa XVI («iOh qué presto de actor verná a ser reo!»), cabe destacar algunas expresiones diseminadas que proyectan la imagen de una afinidad circunstancial, un destino común, entre hombre y fiera. Así, el buitre presagia «alguna bruta o racional ruina» $(\mathrm{XIII}, 8)$ y en el viento «andan envueltas voces y bramidos» $(\mathrm{XV}$, 8); en la estrofa XIV, en el manuscrito de la biblioteca de Ventimiglia el procedimiento queda regularizado, también en el cierre de la octava, al indicar que es «al ave y cazador infausto día ${ }^{48}$. A su vez, el perro, cómplice en la matanza, es caracterizado con un léxico similar al que se aplica a Acteón: «codicioso», como éste ha sido considerado estrofas antes (VII, 3), y azuzado por su «inclinación» $(\mathrm{XV}, 2)$, del mismo modo que en la octava siguiente se refiere la «fatiga a que nació inclinado» el joven (XVI, 4).

La estrofa XVI expresa una implicación incluso física entre la figura de Acteón y lo sangriento del espectáculo: Acteón quiere, en una imagen casi ferina, «matar con sangre bruta que ha sacado / la sed insaciable a su deseo» (XVI, 2-3) y aparece él mismo «ensangrentado» cual sacerdote pagano (XVI, 6); la siguiente octava insiste en la crueldad en el cazador: frente al hombre que niega su «perdón», su «piedad», al más débil oponente, por carácter (el «tímido conejo») o por sexo («la cierva»), sólo el sol actúa como «piadoso amigo».

En las estrofas XVIII-XXIII, la supuesta ponderación de la extenuación a la que han llegado los compañeros de Acteón tampoco está falta de connotaciones negativas:

\footnotetext{
No a mayor diligencia, fugitivas reliquias del ejército deshecho, con alas del temor de ser cautivas, buscan el muro amigo a su despecho, que el tebano escuadrón a las altivas selvas, robadas del estrago hecho, ${ }^{49}$ como a palio corrió a la sombra fría, ${ }^{50}$ huyendo el resplandor, padre del día.

Quién con ardiente sed apenas llega y la espalda del arco se despoja, $\mathrm{y}$ al escaso cristal que un prado riega con fervoroso afecto el pecho arroja, suspende el curso líquido, y sosiega a respirar, y el labio otra vez moja: fuerte pasión hidrópica parece, que se bebe el arroyo, y la sed crece.
}

48 En los demás manuscritos citados: «aleve el cazador, infausto el día».

49 En el manuscrito seguido por Mignone: «robadas al».

50 En el manuscrito seguido por Mignone: «como palio corrió la sombra fría». 
Quién, con hambre villana, el fuego pasa

de las entrañas de la piedra dura a los brazos del pino, verde casa que huéspedes alberga en la espesura; al gamo rasga el vientre y en la brasa arroja palpitando la asadura, con la postrera sangre casi viva, que apenas perdió el alma sensitiva.

A quién tanta fatiga de manera el vigor de los miembros ha robado, que el aura, entre las flores lisonjera, en ellos dulce sueño ha derramado; tener, como Epiménides, quisiera en ocio doce lustros su cuidado y ser imagen viva, en años tales, del pálido terror de los mortales.

El pecho en tierra están, y, ensangrentadas, las manos tienen juntas y tendidas, los canes que, pulsando las ijadas, estriban en las piernas encogidas; las lenguas, anhelando, están sacadas, y las orejas flojas y caídas:

ni al sueño, ni al manjar, ni al agua atentos, sólo con respirar están contentos.

Llevados del afecto o del reposo, yacen el hombre y can sin resistencia, y sólo está en el Príncipe curioso el natural sosiego con violencia, y del cristal que corre perezoso saber quiere la clara descendencia, que sigue (¡oh infelice!) una corriente, nieta de un risco, hija de una fuente.

En la primera de estas estrofas, la imagen bélica rodea la visión de una naturaleza a la vez benigna y ultrajada, en esas selvas «robadas del estrago hecho» que, no obstante, proporcionan sombra a los agotados cazadores; sin embargo, éstos no son comparados a los heroicos vencedores de una lid: su prisa por guarnecerse del sol se plasma en el símil de un ejército diezmado y temeroso de ser apresado que huye hacia las murallas amigas. Análogo cuadro de descompostura sugiere la estrofa siguiente, con la precipitación y avidez con que algún cazador se acerca a beber. Frente a la solemnidad con que, más adelante, Diana va a ser despojada de sus armas y vestiduras por sus ninfas para acogerse a las agradables aguas de la fuente (estrofas XXX-XXXI), aquí el cazador «apenas llega / y la espalda del arco se despoja» (XIX, 1-2) para precipitarse con «fuerte pasión» (XIX, 7), no hacia una fuente atrayente en su abundancia, sino hacia el «escaso cristal que un prado riega» (XIX, 3); de nuevo la desmesura caracteriza su comportamiento («se bebe el arroyo», XIX, 8), ahora con un símil patológico, el 
de la hidropesía, en la época también asociada metafóricamente a la avaricia ${ }^{51}$. En la estrofa XX, la evocación de una naturaleza acogedora con el recuerdo del pino como «verde casa / que huéspedes alberga en la espesura» (XX, 3-4) queda contrastada con una nueva escena de connotaciones negativas: por mano del hombre, piedra y pino encienden el fuego donde se asarán unas vísceras que, evidenciando de nuevo la insensibilidad humana del cazador, aún están "palpitando», «con la postrera sangre casi viva, / que apenas perdió el alma sensitiva» (XX, 7-8), todo ello para satisfacer un hambre significativamente calificada, frente a las connotaciones caballerescas de la caza, como «villana» $(X X, 1)$.

Aunque menos marcadas por evocaciones directamente negativas, las dos octavas dedicadas respectivamente a la fatiga de los hombres y de los perros no abandonan el terreno de lo hiperbólico. El cazador desearía dormir durante sesenta años y, siguiendo la imagen tópica del sueño como imago mortis, «ser imagen viva, en años tales, / del pálido terror de los mortales» (XXI, 7-8). Los perros, con sus manos «ensangrentadas», como antes aparecía Acteón, «ni al sueño, ni al manjar, ni al agua atentos, / sólo con respirar están contentos» (XXII, 7-8). En ambos casos se insiste en la renuncia a cualquier actividad que le sea propia a la naturaleza de cada cual, reducida la voluntad («tener... quisiera», «están contentos») a lo más mínimo de la existencia, «respirar» en los perros -en los que aun el dormitar formaría parte de su imagen cotidiana-, vegetar en prolongado sueño en el hombre. Si ya la contigüidad de las octavas no hubiera advertido al respecto, los versos iniciales de la estrofa XXIII vuelven a mostrar esa imagen conjunta de hombre y animal que, lejos de desprender un mensaje de armonía con la naturaleza, en el contexto del poema parece expresar el rebajamiento de la dignidad humana: «Llevados del afecto o del reposo, / yacen el hombre y can sin resistencia». Casi al final del poema, volverá a mostrarse esta comunión de hombres y perros cuando Acteón, ya convertido en ciervo, aparece «huyendo de su can y de su amigo, / en la traición sin culpa semejantes» (LI, 5-6), y en la estrofa siguiente, desapareciendo la figura humana, pero aún representada ésta en sus armas, «los perros y las flechas le seguían, / igualmente crueles y veloces» (LII, $3-4)$.

Lógicamente, esto se suma a la carga de indefinición entre naturaleza humana y animal que en el texto ovidiano entrañaba la metamorfosis de Acteón, quien mantenía su razón humana, pero perdía otras facultades como el lenguaje articulado, el otro gran rasgo distintivo del hombre. Significativos son al respecto sintagmas como «ciervo humano» (XLVI, 3) o «bruto con razón» (XLIV, 5), al igual que otras expresiones que

51 Hidropesía «algunas veces se toma por la avaricia, porque el hidrópico, por mucho que beba, nunca apaga su sed, ni el avariento, por mucho que adquiera, su codicia» (Covarrubias). 
recuerdan su dual naturaleza. Aparte del seguimiento ovidiano que al respecto realiza Mira de Amescua, recreando la incapacidad de Acteón para articular palabra, quizás sea significativo en este sentido también su original conjunción en un único movimiento de la pérdida de la posición erguida -recuérdese que ésta era igualmente considerada como privilegio humano- y el reconocimiento en las aguas de su nueva figura:

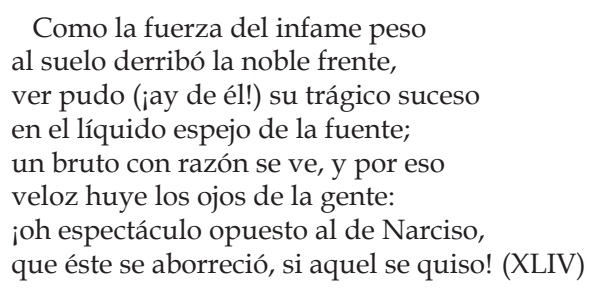

Va siendo hora de recapitular. Mira de Amescua no parece haber tenido intención de aleccionar directamente. Ni segrega la presunta moralidad de la fábula, como hiciera Cristóbal de Castillejo, ni utiliza el relato como ejemplo de atormentados amadores, a través del motivo de la mirada, como Barahona de Soto, en conexión con la propia autobiografía poética. Sin embargo, tampoco parece ignorar los desarrollos ejemplarizantes anejos al mito.

En las propias variantes del episodio, proyectadas en testimonios literarios e iconográficos desde la Antigüedad hasta sus días, pudo encontrar sugerencias en torno al deseo de Acteón, en apariencia el elemento más trasgresor en el comportamiento del joven, pero que, paradójicamente, propicia la caracterización más «humana» del protagonista de Mira de Amescua, con su debilidad y contradicciones.

En el enfoque moralizante sobre la inmoderada afición a la caza pudo hallar una tradición con notable vigor aún, que Mira de Amescua, posiblemente en consonancia con otros autores, reorientó a su criterio. Tal tradición insistía en los peligros económicos y de estatus social, cuando no incluso de bien comunitario, que entrañaba la dejación de obligaciones propias por parte del príncipe o caballero, fueran éstas de orden político, social, de administración doméstica o incluso de formación intelectual y «buenas costumbres». El planteamiento de Mira de Amescua para nada parece apuntar a cuestiones económicas y sólo muy tenuemente se introducen sugerencias 
de índole política o social. En cambio, parece inclinarse por una vertiente humanista, precisamente en torno a consideraciones de la dignidad del hombre ${ }^{52}$. Ya Lía Schwartz recordaba, a propósito del soneto de Quevedo «Primero va seguida de los perros...», la sátira contra los cazadores en el Elogio de la Locura de Erasmo. En Mira de Amescua no es definitoria la idea que articula el pasaje erasmiano, con su contraste entre los aspectos repulsivos de las monterías (el estruendo de la caza, el olor de los perros o lo brutal del despiece de las presas) y el empaque nobiliario concedido a tal actividad; no obstante, su conclusión de la crítica sí resulta próxima: «aunque ésos con su continuo perseguir y comer fieras no consigan más que degenerar hasta ser ellos mismos poco menos que fieras, sin embargo, entretanto piensan que se están dando una vida de reyes» ${ }^{53}$. También cabe recordar la Carta a un amigo, abominando la vida solitaria del cazador de Andrés Rey de Artieda, ya ésta -a diferencia del pasaje erasmiano- incluso con mención explícita del mito de Acteón. Aunque no olvida la faceta económica aducida por la tradición moralizante, y aunque el eje de la crítica se articula, de manera distinta que en Mira de Amescua, en torno al desprecio de la vida tosca del campo en favor de la sociabilidad y refinamiento urbanos, tampoco falta algún pasaje afín al análisis aquí propuesto. Véanse, por ejemplo, los siguientes versos, referidos, en general, al cazador:

\footnotetext{
Como culebra es justo que se enrosque, salga a tomar el sol como lagarto, y como fiero jabalí se embosque.

Con gran razón del gremio humano aparto estos hombres que en bestias se transforman (que harto lo son, pues lo parecen harto), pues la rústica voz vagando forman de nuestro humano pronunciar distinta: tanto con los cuadrúpedes conforman. ${ }^{54}$
}

Posiblemente ésa sea una línea por la que seguir indagando en torno al contexto intelectual de una interpretación no meramente esteticista, pero tampoco unívocamente moralizante de la Fábula de Acteón de Mira de Amescua.

\footnotetext{
52 No faltaron otras interpretaciones de cuño humanista distintas a la aquí apuntada. Por ejemplo, en conjunción con ideas neoplatónicas y herméticas, para Giordano Bruno, «Acteón significa el intelecto aplicado a la caza de la divina sabiduría, a la aprehensión de la belleza divina»; «la voluntad persigue las cosas naturalmente, es decir, según la razón por la cual son en sí. Así Acteón, con esos pensamientos, esos canes que buscaban fuera de sí el bien, la sabiduría, la belleza, la montaraz fiera, por este medio llegó a su presencia; fuera de sí por tanta belleza arrebatado, convirtióse en presa, viose convertido en aquello que buscaba y advirtió cómo él mismo se trocaba en la anhelada presa de sus canes, de sus pensamientos, pues habiendo en él mismo contraído la divinidad, no era necesario buscarla fuera de sí» (Los Heroicos furores, trad. de M. R. González Prada, Tecnos, Madrid, 1987, págs. 72 y 74).
}

53 Cito por la traducción de T. Fanego Pérez, Akal, Madrid, 2004, pág. 118.

54 Discursos, epístolas y epigramas de Artemidoro, Angelo Tavanno, Zaragoza, 1605, fol. 76r. 